\title{
Hubungan Pengetahuan Gizi dan Pola Pemberian Makanan Pendamping Asi Terhadap Status Gizi pada Umur 6-59 Bulan Di Wilayah Kerja Puskesmas Selalong Kecamatan Sekadau Hilir Kabupaten Sekadau
}

\author{
Edi Waliyo $^{1}$ Marlenywati $^{2}$ Nurseha $^{3}$ \\ ${ }^{1}$ Jurusan Gizi Politeknik Kesehatan Kemenkes Pontianak ${ }^{2}$ Peminatan Gizi Kesehatan Masyarakat Fakultas \\ Ilmu Kesehatan Universitas Muhammadiyah Pontianak. ${ }^{3}$ Peminatan Gizi Kesehatan Masyarakat Fakultas Ilmu \\ Kesehatan Universitas Muhammadiyah Pontianak
}

\begin{abstract}
Abstrak
Wasting (gizi kurus) merupakan masalah gizi yang sifatnya akut, sebagai akibat dari peristiwa yang terjadi dalam waktu yang tidak lama seperti kekurangan asupan makanan. Dampak gizi kurus pada balita menurunkan kecerdasan, merasa lesu, mudah marah dan rentan terhadap penyakit infeksi. Tahun 2014 prevalensi wasting di Puskesmas Selalong sebesar 12,5\% lebih tinggi dibandingkan UPK yang ada di Kecamatan Sekadau Hilir. Sekadau sebesar 9,89\%, SP III Trans sebesar 2,60\% dan Simpang Empat sebesar 4,95\%.Penelitian ini bertujuan untuk mengetahui hubungan pengetahuan gizi dan pola pemberian makanan pendamping ASI terhadap status gizi (BB/PB atau BB/TB) pada umur 6-59 bulan di Wilayah Kerja Puskesmas Selalong Kecamatan Sekadau Hilir Kabupaten Sekadau.

Penelitian ini menggunakan desain cross sectional. Sampel penelitian ini sebanyak 84 di ambil dengan menggunakan teknik sampel random sampling. Variabel penelitian diuji menggunakan chisquare dengan derajat ketepatan 95\% $(\alpha=0,05)$.

Hasil penelitian menunjukkan terdapat hubungan yang bermakna antara pengetahuan gizi ( $p$ value $=$ $0,024, \mathrm{PR}=1,657$ dengan CI 95\% $=1,103-2,488)$, jumlah pemberian MP-ASI ( $p$ value $=0,000 ;$ PR $=18,633$ dengan CI 95\% = 4,824-71,975), dan frekuensi pemberian MP-ASI $(p$ value $=0,000, \mathrm{PR}=$ 3,467 dengan CI 95\% = 1,919-6,262) terhadap gizi kurus di Wilayah Kerja Puskesmas Selalong. Variabel yang tidak berhubungan usia pemberian MP-ASI $(p$ value $=0,256$ ) dan jenis pemberian MP-ASI ( $p$ value $=0,065$ ).

Disarankan kepada ibu balita untuk lebih meningkatkan pemantauan pertumbuhan balita setiap bulan melalui posyandu untuk mengetahui status gizi dengan tujuan untuk mencegah dan mendeteksi dini gangguan pertumbuhan dan pola makan anak.
\end{abstract}

Kata kunci : : Wasting, Pengetahuan Gizi, Pola Makan, MP-ASI

Korespondensi: Marlenywati, Peminatan Gizi Kesehatan Masyarakat Fakultas Ilmu Kesehatan Universitas Muhammadiyah Pontianak, J1. 28 Oktober - Siantan Hulu Pontianak, mobile. (0561) 882632 e-mail: marlenywati_83@yahoo.co.id 


\section{Pendahuluan}

Gizi merupakan kebutuhan yang sangat penting dalam proses pertumbuhan, dan perkembangan bayi dan anak. Mengingat manfaat gizi dalam tubuh dapat membantu proses pertumbuhan dan perkembangan anak, serta mencegah terjadinya berbagai penyakit akibat kurang gizi. Selain itu gizi juga dapat membantu dalam aktifitas sehari-hari karena gizi sebagai sumber tenaga, sumber zat pembangun dan pengatur dalam tubuh ${ }^{1}$.

Status gizi balita merupakan status kesehatan yang dihasilkan oleh keseimbangan antara kebutuhan dan asupan dari nutriture dalam bentuk variabel tertentu. Penilaian status gizi merupakan pengukuran yang dapat dilakukan berdasarkan data antropometri atau biokimia. Indikator yang digunakan untuk menentukan status gizi wasting (kurus) adalah dengan menggunakan berat badan menurut tinggi badan $(\mathrm{BB} / \mathrm{TB})$ atau berat badan menurut panjang badan $(\mathrm{BB} / \mathrm{PB})^{2}$.

Status gizi dipengaruhi oleh beberapa faktor, diantaranya adalah Pemberian Makanan Pendamping Air Susu Ibu (MPASI). Makanan Pendamping Air Susu Ibu (MP-ASI) adalah makanan atau minuman yang mengandung zat gizi, diberikan kepada bayi atau anak usia 6-24 bulan guna memenuhi kebutuhan gizi selain ASI. ASI ekslusif adalah pemberian ASI saja sejak bayi dilahirkan sampai usia 6 bulan (Sitompul, 2014) ${ }^{3}$. Di Indonesia cakupan ASI ekslusif masih belum memenuhi target yaitu sebesar
$42 \%$, artinya pemberian MP-ASI yang terlalu dini atau diberikan dibawah umur 6 bulan. Pemberian MP-ASI yang tepat mulai diberikan pada usia 6 bulan dan diberikan 3 kali sehari, karena 6 bulan ASI saja tidak cukup memenuhi kebutuhan bayi, sehingga perlu makanan pendamping ASI.

Pemberian MP-ASI meliputi kapan MPASI harus diberikan, jenis, bentuk dan jumlahnya $^{4}$. MP-ASI harus bergizi dan mempunyai bentuk, jenis dan jumlah yang sesuai dengan umur bayi dan anak. Pemberian makanan seperti bubur beras atau bubur formula yang diberikan pada anak sebagai MP-ASI, namun masih banyak anak yang status gizinya tidak baik, hal ini dikarenakan jumlah MP-ASI yang diberikan masih kurang memadai (Sakti, 2013). Makanan pendamping ASI (MP-ASI) dan status gizi balita memunculkan masalah pada aspek hubungan sebab akibat dimana pemberian MP-ASI yang kurang tepat melahirkan status gizi kurang (wasting) atau gizi buruk ${ }^{5}$.

Dampak defisiensi gizi dapat mempengaruhi perkembangan mental anak. Anak yang kurang gizi akan mengalami penurunan interaksi dengan lingkungannya dan keadaan ini akan menimbulkan perkembangan anak yang buruk. Anak tersebut akan memperlihatkan aktifitas yang menurun, lebih rewel dan merasa tidak bahagia serta tidak begitu menunjukan rasa ingin tahu jika dibandingkan dengan anak yang gizi baik. Akibatnya perubahan yang

Nurseha dkk, Hubungan Pengetahuan Gizi dan Pola Pemberian Makanan Pendamping Asi Terhadap Status 
struktural dan fungsional pada otak akan berpengaruh terhadap tingkat kecerdasan anak $^{6}$.

Masalah kesehatan masyarakat sudah dianggap serius bila prevalensi kurus antara 10,0\%-14,0\%, dan dianggap kritis apabila melebihi $\geq 15 \%$ yaitu sebesar $13,3 \%$ (WHO, 2010) ${ }^{7}$. Di Indonesia, hasil riset kesehatan dasar (RISKESDAS 2013) ${ }^{8}$ menunjukkan bahwa secara nasional prevalensi kurus berdasarkan indikator $(\mathrm{BB} / \mathrm{TB})$ atau berat badan menurut panjang badan $(\mathrm{BB} / \mathrm{PB})$ pada anak balita sebesar $12,1 \%$.

Prevalensi kurus pada anak balita di provinsi Kalimantan barat pada tahun 2011 sebesar 10,54\%. Prevalensi kurus mengalami penurunan pada tahun 2012 sebesar 10,33\% dan prevalensi kurus mengalami penurunan pada tahun 2013 sebesar 10,9\% yang berarti masalah kurus di Kalimantan Barat masuk pada kategori serius ${ }^{9}$.

Prevalensi kurus pada anak balita di kabupaten sekadau pada tahun 2012 sebesar $12,5 \%$, prevalensi kurus mengalami penurunan pada tahun 2013 sebesar $4,83 \%$ dan prevalensi kurus mengalami peningkatan pada tahun 2014 sebesar 4,95\% 10. Perbandingan prevalensi kurus pada anak balita yang terjadi di puskesmas yang ada di kecamatan sekadau hilir pada tahun 2014 adalah prevalensi puskesmas sekadau hilir yang kurus sebesar 9,89\%, prevalensi puskesmas selalong yang kurus sebesar $12,5 \%$, prevalensi puskesmas SP III Trans yang kurus sebesar 2,6\%, dan prevalensi puskesmas simpang emapat yang kurus sebesar 4,9\%. Dari puskesmas yang ada di kecamatan sekadau hilir puskesmas selalong memiliki prevalensi kurus tertinggi dari puskesmas yang ada di kecamatan sekadau hilir yaitu sebesar $12,5 \%$ (Dinkes Kab. Sekadau, 2014).

Adapun tujuan penelitian ini ialah mengetahui hubungan pengetahuan gizi dan pola pemberian MP-ASI terhadap status gizi (BB/PB atau BB/TB) pada Umur 6-59 bulan di Wilayah Kerja Puskesmas Selalong Kecamatan Sekadau Hilir Kabupaten Sekadau.

\section{Metode}

Penelitian ini menggunakan desain Cross Sectional ${ }^{11}$. Waktu yang dibutuhkan dalam penelitian ini mulai bulan Juli sampai Agustus 2015 yang dimulai dengan memasukan surat izin penelitian. Teknik pengambilan sampel dalam penelitian ini menggunakan Proporsional Random Sampling (kocok arisan/ cabut undi) dengan populasi 168 orang, sampel yang diperoleh sebanyak 84 orang. Penelitian ini dibantu oleh enumerator sebanyak 1 orang dari lulusan D3 Gizi. Analisa yang digunakan adalah analisis univariat untuk memperoleh gambaran karakteristik variabel. Analisis bivariat dilakukan unutuk mengetahui hubungan variabel indevenden dan devenden yaitu pengetahuan gizi, usia pemberian MP-ASI, jenis pemberian MP-ASI jumlah pemberian MP-ASI dan frekuensi pemberian MP-ASI 
terhadap status gizi menggunakan uji chaisquare.

\section{Hasil}

Tabel 1. Distribusi Frekuensi Pendidikan dan Pekerjaan

\begin{tabular}{lll}
\hline Variabel & n & $\mathbf{\%}$ \\
\hline Tingkat Pendidikan & & \\
Tamat SD & 26 & 31 \\
Tamat SMP & 40 & 47.6 \\
Tamat SMA & 14 & 16.7 \\
Tamat Perguruan Tinggi & 4 & 4.7 \\
Total & $\mathbf{8 4}$ & $\mathbf{1 0 0}$ \\
Jenis Pekerjaan & & \\
\hline
\end{tabular}

\begin{tabular}{lll}
\hline Petani & 50 & 59.5 \\
Swasta & 3 & 3.6 \\
PNS & 4 & 4.8 \\
Tidak bekerja/ IRT & 27 & 32.1 \\
Total & $\mathbf{8 4}$ & $\mathbf{1 0 0}$
\end{tabular}

Berdasarkan tabel 1 dapat diketahui bahwa sebagian besar responden adalah tamat SMP sebesar 47,6\%, tamat SD 31\%, tamat SMA $16,7 \%$ dan perguruyan tinggi hanya 4,7\%. Pada jenis pekerjaan responden sebagia besar responden bekrja sebagai petani sebsar $59,5 \%$, responden tidak bekerja/IRT sebesar $31,1 \%$, PNS $4,8 \%$ dan swasta $3,6 \%$

Tabel 2. Hubungan Pengetahuan Gizi dan Pola Pemberian MP-ASI Terhadap Status Gizi (BB/PB atau BB/TB) Pada Umur 6-59 Bulan

\begin{tabular}{|c|c|c|c|c|c|c|}
\hline \multirow{3}{*}{ Variabel } & \multicolumn{4}{|c|}{ Status Gizi } & \multirow{3}{*}{ p value } & \multirow{3}{*}{ PR 95\% CI } \\
\hline & \multicolumn{2}{|c|}{ Kurus } & \multicolumn{2}{|c|}{ Tidak Kurus } & & \\
\hline & $\mathbf{n}$ & $\%$ & $\mathbf{n}$ & $\%$ & & \\
\hline \multicolumn{7}{|l|}{ Pengetahuan Gizi } \\
\hline Kurang Baik & 26 & 68.4 & 12 & 31.6 & \multirow[t]{2}{*}{0,024} & \multirow{2}{*}{$\begin{array}{l}1,657 \\
(1,103-2,488)\end{array}$} \\
\hline Baik & 19 & 41.3 & 27 & 58.7 & & \\
\hline \multicolumn{7}{|l|}{ Usia Pemberian MP-ASI } \\
\hline Tidak Baik < 6 bulan & 14 & 66.7 & 7 & 33.3 & \multirow[t]{2}{*}{0,256} & \multirow{2}{*}{$\begin{array}{l}1,355 \\
(0,915-2,007)\end{array}$} \\
\hline Baik $\geq 6$ bulan & 31 & 49.2 & 32 & 50.8 & & \\
\hline \multicolumn{7}{|l|}{ Jenis Pemberian MP-ASI } \\
\hline Tidak Sesuai & 16 & 72.7 & 6 & 27.3 & \multirow{2}{*}{0,065} & \multirow{2}{*}{$\begin{array}{l}1,555 \\
(1,075-2,248)\end{array}$} \\
\hline Sesuai & 29 & 46.8 & 33 & 53.2 & & \\
\hline \multicolumn{7}{|l|}{ Jumlah Pemberian MP-ASI } \\
\hline Kurang $<80 \%$ dari AKG & 43 & 95.6 & 2 & 4.4 & \multirow[t]{2}{*}{0,000} & \multirow{2}{*}{$\begin{array}{l}18,633 \\
(4,824-71,975)\end{array}$} \\
\hline Cukup $\geq 80 \%$ dari $\mathrm{AKG}$ & 2 & 5.1 & 37 & 94.9 & & \\
\hline \multicolumn{7}{|l|}{ Frekuensi Pemberian MP-ASI } \\
\hline Tidak Baik < 2 Kali Sehari & 36 & 80.0 & 9 & 20.0 & \multirow{2}{*}{0,000} & \multirow{2}{*}{$\begin{array}{l}3,467 \\
(1,919-6,262)\end{array}$} \\
\hline Baik $\geq 2$ Kali Sehari & 9 & 23.1 & 30 & 76.9 & & \\
\hline
\end{tabular}

Nurseha dkk, Hubungan Pengetahuan Gizi dan Pola Pemberian Makanan Pendamping Asi Terhadap Status Gizi Pada Umur 6-59 Bulan 
Berdasarkan hasil penelitian yang dilakukan, proporsi pengetahuan gizi kurang baik $(68,4 \%)$ lebih besar jika dibandingkan dengan pengetahuan gizi yang baik $(58,7 \%)$. Dari hasil analisis diperoleh pula nilai $\mathrm{PR}=$ 1,657 dan 95\% $\mathrm{CI}=1,103-2,488$. Jadi dapat disimpulkan bahwa ada hubungan yang signifikan antara pengetahuan gizi ibu dengan status gizi wasting (kurus) di Wilayah Kerja Puskesmas Selalong Kecamatan Sekadau Hilir Kabupaten Sekadau.

Berdasarkan hasil penelitian yang dilakukan, proporsi usia pemberian MP-ASI yang tidak baik $<6$ bulan $(66,7 \%)$ lebih besar jika dibandingkan dengan usia pemberian MPASI yang baik $\geq 6$ bulan (50,8\%). Dari hasil analisis diperoleh pula nilai $\mathrm{PR}=1,355$ dan 95\% CI $=0,915-2,007$, artinya bahwa usia pemberian MP-ASI yang tidak baik $<6$ bulan mempunyai peluang 1,35 kali terjadi wasting (kurus) dibandingkan dengan usia pemberian MP-ASI yang baik usia 6 bulan. Jadi dapat disimpulkan bahwa tidak ada hubungan yang signifikan antara usia pemberian MP-ASI dengan status gizi wasting (kurus) di Wilayah Kerja Puskesmas Selalong Kecamatan Sekadau Hilir Kabupaten Sekadau. Meskipun variabel usia pemberian MP-ASI tidak berhubungan tetapi ada resiko karena nilai PR $>1$.

Hasil analisis dari tabel bivariat menunjukkan bahwa responden yang jenis pemberian MP-ASI tidak sesuai $(72,7 \%)$ lebih besar jika dibandingkan dengan responden yang jenis pemberian MP-ASI yang sesuai (53,2\%). Hasil uji statistik Chi-Square diperoleh signifikan $(p$ value $)=0,065$ ( $p$ value $>0,05)$, menunjukkan bahwa tidak ada hubungan yang bermakna antara jenis pemberian MP-ASI dengan status gizi.

Hasil analisis dari tabel bivariat menunjukkan bahwa responden yang jumlah pemberian MP-ASI kurang $(95,6 \%)$ lebih besar jika dibandingkan dengan responden yang jumlah pemberian MP-ASI yang (94,9\%). Hasil uji statistik Chi-Square diperoleh signifikan $(\mathrm{p}$ value $)=0,000(\mathrm{p}$ value $\leq 0,05)$, menunjukkan bahwa ada hubungan yang bermakna antara jumlah pemberian MPASI dengan status gizi.

Hasil analisis dari tabel bivariat menunjukkan bahwa responden yang frekuensi pemberian MP-ASI tidak baik $(80,0 \%)$ lebih besar jika dibandingkan dengan responden yang frekuensi pemberian MP-ASI yang baik (76,9\%). Hasil uji statistik Chi-Square diperoleh signifikan $(\mathrm{p}$ value $)=0,000(\mathrm{p}$ value $\leq 0,05)$, menunjukkan bahwa ada hubungan yang bermakna antara frekuensi pemberian MP-ASI dengan status gizi.

\section{Diskusi}

Ketidaktahuan para ibu tentang tata cara pemberian makanan pada anak, akan berakibat kepada kesalahan dalam pemilihan bahan makanan, hal ini akan berdampak kepada kesalahan dalam menerapkan pola makan pada anak, sehingga akan menimbulkan gizi kurang (kurus) pada anak. 
Berdasarkan hasil penelitian yang dilakukan, proporsi pengetahuan gizi kurang baik $(68,4 \%)$ lebih besar jika dibandingkan dengan pengetahuan gizi yang baik $(58,7 \%)$. Dari hasil analisis diperoleh pula nilai $\mathrm{PR}=$ 1,657 dan 95\% CI=1,103-2,488. Jadi dapat disimpulkan bahwa ada hubungan yang signifikan antara pengetahuan gizi ibu dengan status gizi wasting (kurus) di Wilayah Kerja Puskesmas Selalong Kecamatan Sekadau Hilir Kabupaten Sekadau.

Penelitian ini sejalan dengan penelitian Khotimah, dkk $(2010)^{12}$ tentang hubungan pengetahuan gizi ibu dan pola makan balita dengan status gizi balita di Puskesmas Gandus Kecamatan Gandus-Palembang, dengan jumlah sampel 80 ibu yang memiliki balita yang membuktikan bahwa ada hubungan yang bermakna antara pengetahuan gizi ibu dengan status gizi balita ( $p$ value $=0,000)$.

Sebagian besar gizi kurus dapat dihindari, apabila kepala keluarga, terutama ibu mempunyai tingkat pengetahuan yang baik mengenai gizi dan kesehatan. Orang tua yang memiliki pengetahuan yang kurang tentang gizi dan kesehan, cenderung tidak memperhatikan kandungan zat gizi dalam makanan keluarganya terutama untuk balita, serta kebersihan makanan tang disantap, sehingga akan mempengaruhi status gizinya.

Begitu juga dengan pemberian MP-ASI pada anak haruslah sesuai dengan waktu dan jenis yang sesuai. Jika anak diberikan makanan terlalu dini akan berdampak buruk bagi kesehatan anak baik diwaktu sekarang maupun waktu mendatang. Seperti rusaknya sistem pencernaan pada anak, tersedak ketika memakannya, resiko alergi dominan terjadi, batuk dan obesitas.

Berdasarkan hasil penelitian yang dilakukan, proporsi usia pemberian MP-ASI yang tidak baik $<6$ bulan $(66,7 \%)$ lebih besar jika dibandingkan dengan usia pemberian MPASI yang baik $\geq 6$ bulan $(50,8 \%)$. Dari hasil analisis diperoleh pula nilai $\mathrm{PR}=1,355$ dan 95\% $\mathrm{CI}=0,915-2,007$, artinya bahwa usia pemberian MP-ASI yang tidak baik $<6$ bulan mempunyai peluang 1,35 kali terjadi wasting (kurus) dibandingkan dengan usia pemberian MP-ASI yang baik usia 6 bulan. Jadi dapat disimpulkan bahwa tidak ada hubungan yang signifikan antara usia pemberian MP-ASI dengan status gizi wasting (kurus) di Wilayah Kerja Puskesmas Selalong Kecamatan Sekadau Hilir Kabupaten Sekadau. Meskipun variabel usia pemberian MP-ASI tidak berhubungan tetapi ada resiko karena nilai PR $>1$.

Hasil penelitian didapatkan bahwa usia pemberian MP-ASI < 6 bulan pada balita sebanyak $21(25,0 \%)$. Hal ini menunjukkan bahwa para ibu mempunyai kendala pada saat memberikan ASI pada anaknya, seperti ASI kurang dan seringnya anak diberikan jajanan yang tidak bergizi sehingga nafsu makan anak menurundan anak telah merasa kenyang.

Hasil analisis dari tabel bivariat menunjukkan bahwa responden yang jenis 
pemberian MP-ASI tidak sesuai $(72,7 \%)$ lebih besar jika dibandingkan dengan responden yang jenis pemberian MP-ASI yang sesuai (53,2\%). Hasil uji statistik Chi-Square diperoleh signifikan $(p$ value $)=0,065$ ( $p$ value $>$ 0,05), menunjukkan bahwa tidak ada hubungan yang bermakna antara jenis pemberian MP-ASI dengan status gizi.

Hasil penelitian ini didukung oleh penelitian Vita dan Abas Dewi (2010) ${ }^{13}$ yang menunjukkan bahwa tidak terdapat pengaruh yang signifikan antara jenis makanan terhadap status gizi anak. Ibu yang memberikan bubur beras atau bubur formula kepada anak sebagai MP-ASI, namun masih ditemukan banyak anak yang status gizinya tidak baik, hal ini juga disebabkan oleh karena jumlah MP-ASI yang diberikan masih kurang memadai.

Pemberian makanan pendamping ASI seperti bubur nasi, bubur susu diharapkan jangan terlalu cair, apabila diberikan terlalu cair maka kandungan energinya akan berkurang. Sebaiknya dalam pembuatan makanan pendamping ASI ditambahkan minyak atau margarin setengah hingga satu sendok teh ke dalam bubur anak untuk meningkatkan kandungan energi serta supaya makanan licin dan mudah ditelan oleh anak.

Hasil analisis dari tabel bivariat menunjukkan bahwa responden yang jumlah pemberian MP-ASI kurang (95,6\%) lebih besar jika dibandingkan dengan responden yang jumlah pemberian MP-ASI yang (94,9\%). Hasil uji statistik Chi-Square diperoleh signifikan $(\mathrm{p}$ value $)=0,000(\mathrm{p}$ value $\leq 0,05)$, menunjukkan bahwa ada hubungan yang bermakna antara jumlah pemberian MPASI dengan status gizi.

Hasil penelitian Briawan dalam Khotimah (2010), mengatakan bahwa anak setiap hari mengkonsumsi nasi tetapi masih banyak ditemukan hanya dua kali sehari dengan jumlah yang sedikit, padahal seharusnya anak harus diberi makan sesering mungkin karena keterbatasan volume perut anak, oleh karena itu walaupun makanan pokok sudah terpenuhi tetapi frekuensi dan jumlah yang kurang maka dapat menyebabkan anak mengalami gizi kurang (kurus).

Penelitian ini sejalan dengan penelitian Pantiawati dalam Dewi (2010), tentang hubungan pola pemberian MP-ASI dengan status gizi balita di desa kaliori kecamatan kalibagor kabupaten bayumas, yang membuktikan bahwa ada hubungan yang bermakna antara pola pemberian MP-ASI dengan status gizi balita. Konsumsi pangan yang tidak cukup energi biasanya juga kurang dalam satu atau lebih zat gizi esensial lainnya. Konsumsi energi dan protein yang kurang selama jangka waktu tertentu akan menyebabkan gizi kurang, sehingga untuk menjamin pertumbuhan, perkembangan, dan kesehatan balita maka perlu asupan gizi cukup. Konsumsi makanan berpengaruh terhadap status gizi seseorang. Kondisi status gizi baik dapat dicapai bila tubuh memperoleh cukup zat-zat yang akan digunakan secara 
efisien, sehingga memungkinkan terjadinya petumbuhan fisik dan perkembangan otak untuk mencapai tingkat kesehatan optimal.

Frekuensi makan dan jumlah makanan yang diberikan harus menyesuaikan kapasitas lambung bayi. Pemberian makanan pendamping ASI yang tepat biasanya 2-3 kali sehari, memberikan makanan pendamping ASI dalam frekuensi yang berlebihan atau diberikan lebih dari 3 kali sehari, kemungkinan dapat mengakibatkan terjadinya diare $^{14}$.

Hasil analisis dari tabel bivariat menunjukkan bahwa responden yang frekuensi pemberian MP-ASI tidak baik $(80,0 \%)$ lebih besar jika dibandingkan dengan responden yang frekuensi pemberian MP-ASI yang baik (76,9\%). Hasil uji statistik Chi-Square diperoleh signifikan $(\mathrm{p}$ value $)=0,000(\mathrm{p}$ value $\leq 0,05)$, menunjukkan bahwa ada hubungan yang bermakna antara frekuensi pemberian MP-ASI dengan status gizi.

Penelitian ini didukung oleh penelitian Firdhani dan Gunanti dalam khotimah (2012) yang menunjukkan bahwa ada hubungan frekuensi pemberian MP-ASI pada anak dengan kejadian diare. Hal ini menunjukkan bahwa anak yang diberi MP-ASI dengan frekuensi yang tidak tepat, kemungkinan

Tidak mempunyai resiko lebih besar untuk terpapar diare dibanding dengan anak yang diberi MP-ASI dengan frekuensi yang tepat. Keadaan ini menunjukkan bahwa ketidaktahuan akan kaedah makanan bagi kesehatan tubuh menjadi penyebab buruknya mutu gizi makanan keluarga, khususnya makanan

\section{Kesimpulan}

Kelengkapan diagnosa utama dan prosedur utama cukup tinggi dapat disimpulkan bahwa resume medis untuk variable diagnose utama dan prosedur utama pengisiannya sudah cukup lengkap. Untuk variabel diagnose sekunder ketidaklengkapan pengisiannya masih cukup tinggi yaitu sebesar $39 \%$, dikarenakan sering terjadinya salah penempatan dan belum jelasnya kriteria yang masuk kedalam diagnosa sekunder. Dari hasil penelitian ini tidak ada hubungan antara kesesuaian tarif INA-CBGs dengan prosedur utama, hal ini disebabkan prosedur/ tindakan telah tercatat dengan baik, diantaranya tindakan penunjang (laboratoriu, radiologi dll), tindakan keperawatan (Infus, Injeksi dll), Pemeriksaan dokter telah otomatis tercoding, karena pada dasarnya tindakan-tindakan tersebut biasanya dientri oleh perawat kedalam aplikasi komputer yang ada diruangan sehingga untuk prosedur standar akan muncul pada saat pengkodingan di Instalasi rekam medik. Ketidaklengkapan pengisian rekam medis disebabkan pengisi resume medis bukan dokter yang bertanggung jawab melakukan hal itu, Standar Prosedur Operasional belum dijalankan dengan optimal, belum adanya reward dan punisment secara langsung, belum adanya sistem sosialisasi yang berkesinambungan. Berikutnya tentang potensi

Nurseha dkk, Hubungan Pengetahuan Gizi dan Pola Pemberian Makanan Pendamping Asi Terhadap Status 
ketidaksesuaian besaran tarif INA-CBGs dikarenakan ketidaklengkapan resume medis. Oleh karena itu kelengkapan sebuah resume medis sangat berpengaruh terhadap pendapatan rumah sakit.

\section{Saran}

Mengadakan pemantauan pertumbuhan setiap bulan melalui posyandu dan kelompok

\section{Daftar Pustaka}

1. Yogi, Etiak Desi. 2014. Pengaruh Pola Pemberian ASI dan Pola Makanan Pendamping ASI Terhadap Status Gizi Bayi Usia 6-24 Bulan Vol.2 No.1 http://akbidharapanmulya.ac.id/atm/kont en/editor/samples/jurnal/file jurnal/t 21.pdf. Diakses tanggal 25 maret 2015.

2. Supriasa, I Dewa Nyoman. dkk. 2012. Penilaian Status Gizi. Jakarta: EGC.

3. Sitompul, Ewa Monika. 2014. Buku Pintar MPASI. Jakarta: Hak Cipta.

4. Jamilah. 2007. Hubungan Pengetahuan dan Sikap dengan Perilaku Ibu dalam Pemberian Makanan Pendamping ASI (MP-ASI) dini pada Bayi Umur 0-6 bulan di Puskesmas Pal V Kota Pontianak. Skripsi. (tidak dipublikasikan)

5. Sakti, Risky Eka.dkk. 2013. Hubungan Pola Pemberian MP-ASI dengan Status Gizi Anak Usia 6-23 Bulan di Wilayah Pesisir Kecamatan Tallo Kota Makasar. http://repository.unhas.ac.id/bitstream/ha ndle/123456789/5480/JURNAL_MKMI. pdf. Diakses tanggal 25 maret 2015.

6. Gibney, Michael J.dkk. 2009. Gizi Kesehatan Masyarakat. Jakarta: EGC. penimbangan yang sudah ada terhadap status gizi anak serta melakukan pengukuran berat badan/ tinggi badan (BB/TB) atau berat badan/ panjang badan (BB/PB) balita untuk mencegah dan mendeteksi dini gangguan pertumbuhan dan pola makan anak.

7. WHO, 2010. World Health Organization.

8. Kemenkes RI. 2013. Riset Kesehatan Dasar (RIKESDAS). Badan Penelitian dan Pengembangan Kesehatan. Jakarta.

9. Dinkes, Provinsi Kalbar. 2011, 2012, 2013. Profil Dinas Kesehatan Kalimantan Barat. Pontianak

10. Dinkes, Kabupaten Sekadau. 2012, 2013, 2014. Profil Dinas kabupaten sekadau. Sekadau

11. Saepudin, Malik. 2011. Metodologi Penelitian Kesehatan Masyarakat. Jakarta: CV. Trans Info Media.

12. Khotimah, Nyimas Nur. dkk. 2012. Hubungan Pengetahuan Gizi dan Pola Makanan Balita dengan Status Gizi Balita 12-59 bulan di wilayah kerja puskesmas gandus kecamatan Gandus$\begin{array}{lll}\text { Palembang } & \text { Vol.6 } & \end{array}$ http://balitbangnovdasumsel.com/data/do wnload/20140203110042.pdf Diakses tanggal 25 Maret 2015

13. Dewi, Ratna Kartika. 2010. Hubungan Pola Pemberian Makanan Pendamping ASI (MP-ASI) dengan Status Gizi pada Balita Usia 6-12 Bulan di Desa Kaliori Kecamatan Kalibagor Kabupaten $\begin{array}{lllll}\text { Bayumas } & \text { Vol. } & 1 & \text { No. } & 1\end{array}$ 
http://download.portalgaruda.org/article. php article $=200717 \&$ val $=6633 \&$ title

Diakses tanggal 25 Maret 2015
14. Depkes RI. 2007. Departemen Kesehatan Republik Indonesia. Badan Penelitian dan Pengembangan Kesehatan. Jakarta 